\title{
IMPORTANCE OF REFORMS AND INTERNATIONALIZATION OF HIGHER EDUCATION IN ACCORDANCE WITH THE BOLOGNA PROCESS
}

\begin{abstract}
Higher education reform process introduced many innovations in educational systems and caused the passing many new regulations in this area. European knowledge society rests on two pillars - European Resaerch Area - ERA and European Higher Education Area - EHEA. EHEA is being developed through international cooperation and academic exchange that is performed through government ministries, institutions of higher education, and students and teaching staff. It must be emphasized that economic and cultural globalization has imposed new challenges for the system of higher education. Internationalization of higher education is seen as one of the ways a country responds to the impact of globalization. Also, an important feature of the Bologna Process is the adoption of new approaches in higher education. One of them is concept Open Educational Resources. As can be seen in the paper, the Bologna Process represents a strategic transformation of higher education institutions, and the conclusion is that reform process in higher education leads to economic and social well-being of the country.
\end{abstract}

Keywords: Higher education, EHEA, Internationalization, Bologna Process, OER

\footnotetext{
* Associate Professor, The University of Business Academy, Faculty of Law for Commerce and Judiciary, Novi Sad, e-mail: jelena@pravni-fakultet.info

** Assistant Professor, The University of Business Academy, Faculty of Law for Commerce and Judiciary, Novi Sad, e-mail: majasubotin@yahoo.com
} 


\section{Introduction}

Changes in educational systems of most European countries are an unavoidable part of the process of European integrations. Higher education reform process introduced many innovations in educational systems and caused the passing many new regulations in this area. Of course, the goal of these reforms is to erase educational borders and to allow students from all countries, especially students from so-called undeveloped countries, to continue their education abroad and upgrade the knowledge they acquired on postgraduate studies on some of the renowned European universities, to create students who are able to quickly integrate into a working environment due to practical thinking they developed during their university studies; also to leave theory to researchers and professors, and to prepare students for the future venture into the real world, providing them with employment in accordance with their abilities.

The Bologna Process was launched in 1999 by 30 countries to create convergence between higher education systems as the European countries had their specific higher education systems where degrees and academic years were inconsistent. This was aimed at establishing a single integrated framework as a European Higher Education Area (EHEA) and the international recognition of qualifications by member countries by National Quality Assurance Agencies, uniform degree structures, adoption of a common credit transfer system, common way of describing the qualification ("Diploma Supplement") and focus on lifelong learning.

This paper primary reviews the theoretical underpinnings on the process of reforms and internationalization in higher education.

\section{The principles of Bologna Process}

European knowledge society rests on two pillars - European Resaerch Area - ERA and European Higher Education Area - EHEA. Their implementation has a special strategic position in the European integration. ${ }^{1}$

According to official data, the ERA envolves around six priorities: "more effective national research systems; optimal transnational co-operation and competition, including 'optimal transnational cooperation and competition'

\footnotetext{
${ }^{1}$ Komnenović, B., (2005). Serbia and Montenegro in the European area of science, research and higher education, in B. Komnenović (ed.) European area of science, research and higher education - opportunities of Serbia and Montenegro, Alternative Academic Educational Network, Belgrade, p. 7.
} 
and 'Research Infrastructures'; an open labour market for researchers; gender equality and gender mainstreaming in research; optimal circulation, access to and transfer of scientific knowledge, including 'Knowledge circulation' and 'Open Access'; international cooperation". ${ }^{2}$

The creation and development of European Higher Education Area is known as the Bologna Process.

European Higher Education Area (EHEA) is being developed through international cooperation and academic exchange that is performed through government ministries, institutions of higher education, and students and teaching staff.

In order to achieve the goals of the Bologna Process, European countries must fulfill the following tasks:

1. Create a national qualification framework compatible with the general qualification framework of European Higher Education Area.

2. Create a system of quality assurance in accordance with European Standards and Guidelines for Quality Assurance it the European Higher Education Area.

3. Create a system of qualification and diploma approval in accordance with the Convention on the Recognition of Qualifications established by the Council of Europe and UNESCO (Lisbon Convention). ${ }^{3}$

One of the priorities of Bologna Process is the development of National Qualifications Framework (NQF), which should provide us with description of all qualifications that are a part of a national system of higher education, with an emphasis on what the bearers of qualifications can do, what they understand, and what can they do based on the qualifications they acquired (learning results). The framework should also outline the mutual connections of different qualifications within the system, as well as how the students can move between them. National framework should be constructed in accordance

\footnotetext{
2 European Commission (2017). ERA Progress Report 2016 - Report from the Commission to the Council and the European Parliament The European Research Area: Time for implementation and monitoring progress $\operatorname{COM}(2017)$ 35, Directorate-General for Research and Innovation, Luxembourg: Publications Office of the European Union, p. 3.

${ }^{3}$ Convention on the Recognition of Qualifications concerning Higher Education in the European Region, ETS No. 165, Lisbon, 11/04/1997. See also: Matijašević, J., Spalević, Ž., Stefanović, N. (2020). Higher Education in the Republic of Serbia - the Reform in Accordance with the Bologna Process , in Denis Čurčić i Tina Jazbec (eds.), Living Together in the Multi-cultural Society, Emuni University, Portorož, Slovenij, 426-433, p. 428.
} 
with the General Qualifications Framework in European Higher Education Area adopted by European secretaries of education in Bergen in 2005.

Just as other participants in the Bologna Process, during the reform of higher education and as inseparable part of it, Serbia is developing the National Qualifications Framework that corresponds with the General Qualifications Framework in EHEA, through the process of accreditation of institutions of higher learning and their study programs.

As some authors point out, "among the priorities of the Bologna Process are: the adoption of a common framework for comparability of qualifications and diplomas; the introduction of joint degrees study in all countries (two-stage study); introduction of the European Credit Transfer System; introduction of European standards for quality assurance of higher education; smooth movement of students and teachers within the single European area, regardless of country / system from which it comes and to which it goes; the inclusion of doctoral studies into a single system EHEA and ERA; the development of lifelong learning".

So, according to official data, "it should be emphasized that Adult Education is a subject of great interest to the European Union. A series of reports over the last few years have made it clear that the EU has considerable catching up to do in order to match the level of education of other advanced economies. Alarmingly, one in five adults have low literacy and numeracy skills, one in four have completed lower secondary education at most and one in three have very low or no ICT skills. While progress is being steadily made, considerably more work needs to be done". 5

\section{Goals of accreditation of institutions and study programs}

Accreditation of institutions and study programs of higher education is one of the requirements of Bologna Process and it represents a generally accepted methodology and an instrument of higher education evaluation and quality control since 1990 . The starting point for standardization and accreditation in the area of higher education was the spirit of Graz Declaration ${ }^{6}$ determined by European University Association (EUA). ${ }^{7}$

\footnotetext{
${ }^{4}$ Komnenović, B., op. cit., p. 8.

${ }_{5}^{5}$ Directorate-General for Internal Policies, Policy Department B: Structural and Cohesion Policies (2015). Culture and Education: Research for Cult Committee - Adult Education and Open Educational Resources, Study, European Union, p. 11.

${ }^{6}$ European University Association, Graz Declaration - Forward from Berlin: the role of Universities, Bruxelles, 07/09/2003.

${ }^{7}$ Arsovski Z., Arsovski S., Lazić M., (2007). Quality and accreditation in higher education, Quality - the magazine for the promotion of quality 17 (1-2), 61-65.
} 
Europe does not have a unique methodology and system of institutional evaluation of institutions of higher education. Accreditation of these institutions is often integrated with measures of securing and improving the quality of education. Harmonization and improvement of the accreditation process is being achieved through the European Consortium for Accreditation (ECA). The development of national accreditation systems is based on demands and standards of the European Consortium, Bologna Process, and international standards of quality, as well as on demands and standards of other international organizations, such as: International Network of Quality Assurance Agencies in Higher Education (INQAAHE), European Network for Quality Assurance in Higher Education (ENQA), European University Association (EUA), as well as the methodology and experience of agencies specialized in quality evaluation and accreditation of institutions and study programs of higher education, such as the renowned US Accreditation Board for Engineering and Technology (ABET), etc. ${ }^{8}$

Accreditation of higher education includes the accreditation of:

- Educational and study programs (the procedure of evaluation of study programs and determination of their statuses. It is based on the evaluation of congruency between study programs and the requirements determined by national accreditation standards), and

- Institutions of higher education (the procedure of acquiring the status of the institution of higher learning within the national system of educational institutions. It is based on the analysis of compliance with demands determined for institutions of higher education of certain type and category).

\section{Internationalization of higher education - principles and goals}

Economic and cultural globalization has imposed new challenges for the system of higher education. Every research university is part of a single world-wide network and as a result research is more internationalized than ever before. ${ }^{9}$

\footnotetext{
${ }^{8}$ Lazić, M. (2007). Accreditation in higher education in Festival quality 2007, Association for Quality and Standardization of Serbia, Belgrade, 1-9, p. 2.

9 Vapa-Tankosić, J., Matijašević, J., Lazar, M. (2010). Internationalization of Higher Education: Strengthening HE Educational Reforms in Serbia on the Trajectory of EU Integration in Proceedings from International Conference \& Workshops on Higher Education, Partnership and Innovation, Budapest College of Communication and Business, p. 245.
} 
According to Qiang, "internationalization of higher education is seen as one of the ways a country responds to the impact of globalization, yet at the same time respects the individuality of the nation". ${ }^{10}$

Key analyses of internationalization in higher education point to a broad range of international dimensions in higher education. ${ }^{11}$ According to Knight "internationalization is changing the world of higher education, and globalization is changing the world of internationalization". ${ }^{12}$

The term internationalization has been employed regarding several themes as the physical mobility of students, academic staff, and occasionally administrative staff, as the obviously the most visible international activity, which is in the forefront of programs aiming to promote internationalization. Recognition across borders of study achievements is a second major theme which, naturally, is clearly linked to the first one: are the results of learning in one country accepted as equivalent to that which is expected to be learned in another country. Various programs for the support of student mobility were established with the hope, that cognitive enhancement would be accompanied with attitudinal change: growing "global understanding", more favorable views of the partner country, a growing empathy with other cultures, etc. ${ }^{13}$

Yang argues that "internationalization lies in an understanding of the universal nature of the advancement of knowledge" 14 that is based on the common bonds of humanity, while Knight underlines that internationalization of higher education should help enhance students competencies and create a culture or climate on campus that promotes and supports international and intercultural understanding. ${ }^{15}$

The approach of Kondakci, Van den Broecke and Devos emphasizes that internationalization "is not simply an issue of managing student mobility

\footnotetext{
${ }^{10}$ Qiang, Z. (2003). Internationalization of Higher Education: towards a conceptual framework, Policy Futures in Education, 1 (2), p. 249.

11 De Wit H. (2002). Internationalisation of Higher Education in the United States and Europe. Westport, CT, Greenwood. See also: Van der Wende M. (2001). Internationalisation policies: about new trends and contrasting paradigms, Higher Education Policy, 14 (3), pp. 249-259; OECD (2004). Internationalisation and Trade in Higher Education: Opportunities and Challenges, Paris.

${ }^{12}$ Knight J. (2004). Internationalization remodelled: definition, approaches, and rationales, Journal of Studies in International Education, 8 (1), 5-31, p. 5.

${ }_{13}$ See more: Altbach P., Teichler U. (2001). Internationalisation and exchanges in a globalized university, Journal of Studies in International Education, 5 (1), 5-25; Teichler U. (2009). Internationalisation of higher education: European experiences, Asia Pacific Education Review, 10, p. 93.

${ }^{14}$ Yang, R. (2002). University internationalization: its meanings, rationales and implications, Intercultural Education, 13 (1), p. 85.

${ }^{15}$ Knight J., op. cit., p. 5.
} 
but an issue of strategic transformation of the Higher Education institutions". ${ }^{16}$ They further argue that perceiving internationalization as a managerial issue, which touches structural-functional domains of the organization, and conceptualizing it as an organizational change process is a necessary first step toward successfully developing international dimension into core functions of $\mathrm{HE}$ institutions.

After all said, Knight's presented a typology of four in order to elaborate on the approaches to internationalize:

- activity approach (bringing international student body, developing or joining exchange programs),

- competency approach (change in the knowledge, skills, interests, values, and attitudes of different groups of in the organization),

- ethos approach (developing a culture and climate which facilitates internationalization) and,

- process approach (developing an international aspects not only into academic aspects of the organization but also managerial aspect) as four basic approaches to internationalize. ${ }^{17}$

Internationalisation of higher education in less-developed countries has been developed in different frameworks indicating less systematic or strategic approach under the umbrella of changes from transition to a market economy. Internationalization must support the third countries integration into the developed economic community. Internationalization has many benefits for higher education EU accession countries during its transitional period, but it raises many challenges as well. The challenges range from macro (institutional) to micro-level (changes in the structure of managerial habits). ${ }^{18}$

According to Jibeen and Asad Khan, the internationalization of higher education can be beneficial in sustaining and growing science and scholarship through dynamic academic exchanges; and building social and economic capacity in developing countries. The western universities are establishing powerful international networks and associations to mobilize aptitude and

\footnotetext{
${ }^{16}$ Van Den Broeck, H., Kondakci, Y., \& Devos, G. (2006). More management concepts in the academy: internationalization as an organizational change process. Vlerick Leuven Gent Working Paper Series. Gent; Belgium, Vlerick Leuven Gent Management School, p. 9.

17 Knight, J. (1994). Internationalization: Elements and checkpoints, no. 7, Ottawa, Canada, Canadian Bureau for International Education; According to: Vapa-Tankosić, J., Matijašević, J., Lazar, M., op. cit., p. 246.

${ }^{18}$ See more: Vapa-Tankosić, J., Matijašević, J., Lazar, M., op. cit., p. 247.
} 
ability in favor of transfer of knowledge, advanced policies and global research for enhancing investment and measuring impact". ${ }^{\text {" }}$

The authors also cite other good features of internationalization. For instance, ,the internationalization of education also facilitates in engendering the "international characteristics" fostered in students that are desirable in a global economy such as international-mindedness and open mindedness, second language competence, flexibility of thinking, tolerance and respect for others"..$^{20}$

\section{New approaches in higher education - Open Educational Resources}

An important feature of the Bologna Process is the adoption of new approaches in higher education. One of them is concept Open Educational Resources (OER).

Experts who support OER, highlight the following benefits of this modern approach to education: open access to content for educational institutions and teachers, students and lifelong learners, etc; content is often designed for easy re-use in that open content standards and formats; the availability of relevant applications, software, etc. ${ }^{21}$

In its simplest form, according to Butcher, "the concept of OER describes any educational resources (including curriculum maps, course materials, textbooks, streaming videos, multimedia applications, podcasts, and any other materials that have been designed for use in teaching and learning) that are openly available for use by educators and students, without an accompanying need to pay royalties or licence fees". ${ }^{22}$ According to the views of many authors, "OER movement originated from developments in Open (free) Learning, Distance Learning and the broad context of a culture of Open Learning, Open

\footnotetext{
19 Jibeen, T., Asad Khan, M. (2015). Internationalization of Higher Education: Potential Benefits and Costs, International Journal of Evaluation and Research in Education (IJERE), 4(4), p. 197.

${ }^{20}$ Hayden, MC., Thompson, J., Williams, G. (2003). Student perceptions of international education: A comparison by course of study undertaken, Journal of Research inInternational Education, 2(2), pp. 205-232; Chan, WW., Dimmock.C. (2008). The Internationalization of universities: Globalist, internationalist and translocalist models, Journal of Research in International Education, 7(2), pp. 184-204.

${ }^{21}$ Open e-Learning Content Observatory Services (OLCOS) (2007). Open Educational Practices and Resources, OLCOS Roadmap 2012 - Project, G. Geser (ed.), Austria, Salzburg Research/ EduMedia Group, p. 20.

${ }^{22}$ Butcher, N. (2015). A Basic Guide to Open Educational Resources (OER), France, Paris, United Nations Educational, Scientific and Cultural Organization (UNESCO) and Canada, Vancouver, Commonwealth of Learning, p. 5.
} 
Source, free sharing and many others who have appeared at the end of the 20 th century". ${ }^{23}$ The OER has provided great support for significant changes in education. Its transformative power lies in the easy handling of digitized educational resources. What significantly differentiates OER and other contemporary approaches to education is the existence of a license. Thus, "an OER is simply an educational resource that incorporates a licence that facilitates reuse, and potentially adaptation, without first requesting permission from the copyright holder". ${ }^{24}$

According with that, OER concept include learning content, adequate software to support the development and use of learning content and intellectual property licences to promote open publishing of materials, as well as the necessary ethical standards in this process. ${ }^{25}$

Therefore, according to Conole, "the OER movement argues that educational materials should be freely available for learners and teachers as a fundamental human right", ${ }^{26}$

In contrast to traditional education OER concept offers different possibilities to learners and teaching staff.

Given this, the transformative educational potential of OER revolves around three linked possibilities:

"1. Increased availability of high quality, relevant learning materials can contribute to more productive students and educators;

2. The principle of allowing adaptation of materials provides one mechanism amongst many for constructing roles for students as active participants in educational processes, who learn best by doing and creating, not by passively reading and absorbing;

3. OER has potential to build capacity by providing institutions and educators access, at low or no cost, to the means of production to develop their competence in producing educational materials and carrying

\footnotetext{
${ }^{23}$ Mossley, D. (2013). Open Educational Resources and Open Education, United Kingdom, The Higher Education Academy (HEA); See more: Wiley, D. (2007). On the Sustainability of Open Educational Resource Initiatives in Higher Education, OECD, Centre for Educational Research and Innovation (CERI) for the project on Open Educational Resources.

${ }^{24}$ Butcher, N., op. cit., p. 5.

${ }^{25}$ Centre for Educational Research and Innovation (CERI) (2007). Giving Knowledge for Free The emergence of Open Educational Resources, Paris, Organisation for Economic Co-operation and Development (OECD) Publicatons, pp. 30-31.

${ }^{26}$ Conole, G. (2012). Integrating OER into Open Educational Practices in J. Glennie, K. Harley, N. Butcher \& T. V. Wyk (Ed.), Perspectives on Open and Distance Learning: Open Educational Resources and Change in Higher Education: Reflections from Practice, Vancouver, The Commonwealth of Learning, p. 112.
} 
out the necessary instructional design to integrate such materials into high quality programmes of learning". ${ }^{27}$

How important is the use of OER by the fact that the European OER's record increase of users, the majority of this number is calculated from several hundred thousand registered users and up to several million. In the USA the number is much higher. In Serbia, the OER inserted into the Strategy of Higher Education by 2020, which is based on the openness of Education. ${ }^{28}$

\section{Conclusion}

Higher education plays an important role in supporting the economical and cultural advancement in Serbia, and these reforms are based on advanced knowledge and skills in numerous areas. The changes in higher education are necessary for democratic progress of the Serbian society as a whole, but also the institutions of higher education themselves. Reform process in higher education leads to economic and social well-being of the country.

As can be seen in the paper, the reform of higher education have a direct impact on the various aspects of internationalization.

Relying on what was said, the Bologna Process represents a strategic transformation of higer education institutions and a process of reshaping internal higher education structure. At the institutional level, it relies heavily on the governments' effort to invent different means to support the Universities in the reform, thus making the system of higher education more flexible and responsive to the needs of the labour market and of the knowledge society.

\footnotetext{
${ }^{27}$ Butcher, N., op. cit., p. 13. See more: Matijašević-Obradović, J., Banović, B., Joksić, I. (2019). Open Education Europa - opportunities for improvement of Higher Education Area in Serbia, Teme, 43 (1), p. 212.

${ }^{28}$ Milošević, D, Milošević, M., Radović, M. (2015). Open Educational Resources in Education (Initial Report) in A. Veljović (Ed.), Business Process Reengineering in Education - RPPO 2015, Čačak: Faculty of Technical Sciences, 37-45.
} 


\title{
Matijašević Obradović Jelena
}

Vanredni profesor, Pravni fakultet za privredu i pravosuđe u Novom Sadu, Univerzitet

Privredna akademija u Novom Sadu

\section{Subotin Maja}

Docent, Pravni fakultet za privredu i pravosuđe u Novom Sadu, Univerzitet Privredna akademija u Novom Sadu

\section{ZNAČAJ REFORMI I INTERNACIONALIZACIJE VISOKOG OBRAZOVANJA U SKLADU SA BOLONJSKIM PROCESOM}

\author{
Re zime
}

Proces reforme visokog obrazovanja uveo je mnoge inovacije u obrazovne sisteme i doveo do donošenja mnogih novih propisa u ovoj oblasti. Evropsko društvo znanja počiva na dva stuba - Evropskom istraživačkom prostoru i Evropskom prostoru visokog obrazovanja. Evropski prostor visokog obrazovanja se kontinuirano razvija putem međunarodne saradnje i akademske razmene, koje se pak realizuju preko ministarstva, institucija visokog obrazovanja, a uključuju studente i nastavno osoblje. Mora se naglasiti da je ekonomska i kulturna globalizacija nametnula nove izazove sistemu visokog obrazovanja. Internacionalizacija visokog obrazovanja se smatra jednim od načina na koji država reaguje na sve izraženiji uticaj globalizacije. Takođe, važna karakteristika Bolonjskog procesa je usvajanje novih pristupa u visokom obrazovanju. Jedan od tih pristupa je svakako koncept Otvorenih obrazovnih resursa. Kao što se u radu može videti, Bolonjski proces predstavlja stratešku transformaciju visokoškolskih ustanova i zaključak koji se nameće jeste da proces reformi u visokom obrazovanju svakako dovodi do ekonomskog i socijalnog blagostanja države.

Ključne reči: visoko obrazovanje, Evropski prostor visokog obrazovanja, Internacionalizacija, Bolonjski proces, Otvoreni obrazovni resursi 


\section{Literature}

1. Altbach P., Teichler U., (2001). Internationalisation and exchanges in a globalized university, Journal of Studies in International Education, 5 (1), pp. 5-25

2. Arsovski Z., Arsovski S., Lazić M., (2007). Quality and accreditation in higher education, Quality - the magazine for the promotion of quality 17 (1-2), pp. 61-65

3. Butcher, N., (2015). A Basic Guide to Open Educational Resources (OER), France, Paris, United Nations Educational, Scientific and Cultural Organization (UNESCO) and Canada, Vancouver, Commonwealth of Learning

4. Centre for Educational Research and Innovation (CERI) (2007). Giving Knowledge for Free - The emergence of Open Educational Resources, Paris, Organisation for Economic Co-operation and Development (OECD) Publicatons

5. Conole, G., (2012). Integrating OER into Open Educational Practices in J. Glennie, K. Harley, N. Butcher T. V. Wyk (Ed.), Perspectives on Open and Distance Learning: Open Educational Resources and Change in Higher Education: Reflections from Practice, Vancouver, The Commonwealth of Learning, pp. 111-124

6. Convention on the Recognition of Qualifications concerning Higher Education in the European Region, ETS No. 165, Lisbon, 11/04/1997

7. Chan, WW., Dimmock, C., (2008). The Internationalization of universities: Globalist, internationalist and translocalist models, Journal of Research in International Education, 7(2), pp. 184-204

8. De Wit H., (2002). Internationalisation of Higher Education in the United States and Europe. Westport, CT, Greenwood

9. Directorate-General for Internal Policies, Policy Department B: Structural and Cohesion Policies (2015). Culture and Education: Research for Cult Committee - Adult Education and Open Educational Resources, Study, European Union

10. European University Association, Graz Declaration - Forward from Berlin: the role of Universities, Bruxelles, 07/09/2003

11. European Commission (2017). ERA Progress Report 2016 - Report from the Commission to the Council and the European Parliament The European Research Area: Time for implementation and monitoring progress $\operatorname{COM}(2017) 35$, Directorate-General for Research and Innovation, Luxembourg: Publications Office of the European Union 
12. Hayden, MC., Thompson, J., Williams, G., (2003). Student perceptions of international education: A comparison by course of study undertaken, Journal of Research inInternational Education, 2 (2), pp. 205-232

13. Jibeen, T., Asad Khan, M., (2015). Internationalization of Higher Education: Potential Benefits and Costs, International Journal of Evaluation and Research in Education (IJERE), 4 (4), pp. 196-199

14. Knight, J., (1994). Internationalization: Elements and checkpoints, no. 7, Ottawa, Canada, Canadian Bureau for International Education

15. Knight J., (2004). Internationalization remodelled: definition, approaches, and rationales, Journal of Studies in International Education, 8 (1), pp. 5-31

16. Komnenović, B., (2005). Serbia and Montenegro in the European area of science, research and higher education, in B. Komnenović (ed.) European area of science, research and higher education - opportunities of Serbia and Montenegro, Alternative Academic Educational Network, Belgrade, pp. $7-15$

17. Lazić, M., (2007). Accreditation in higher education in Festival quality 2007, Association for Quality and Standardization of Serbia, Belgrade, pp. 1-9

18. Matijašević, J., Spalević, Ž., Stefanović, N., (2020). Higher Education in the Republic of Serbia - the Reform in Accordance with the Bologna Process, in Denis Čurčić i Tina Jazbec (eds.), Living Together in the Multi-cultural Society, Emuni University, Portorož, Slovenij, pp. 426-433

19. Matijašević-Obradović, J., Banović, B., Joksić, I., (2019). Open Education Europa - opportunities for improvement of Higher Education Area in Serbia, Teme, 43 (1), pp. 209-222

20. Milošević, D, Milošević, M., Radović, M., (2015). Open Educational Resources in Education (Initial Report) in A. Veljović (Ed.), Business Process Reengineering in Education - RPPO 2015, Čačak: Faculty of Technical Sciences, pp. 37-45

21. Mossley, D., (2013). Open Educational Resources and Open Education, United Kingdom, The Higher Education Academy (HEA)

22. OECD (2004). Internationalisation and Trade in Higher Education: Opportunities and Challenges, Paris

23. Open e-Learning Content Observatory Services (OLCOS) (2007). Open Educational Practices and Resources, OLCOS Roadmap 2012 - Project, G. Geser (ed.), Austria, Salzburg Research/ EduMedia Group

24. Qiang, Z., (2003). Internationalization of Higher Education: towards a conceptual framework, Policy Futures in Education, 1 (2), pp. 248-270 
25. Teichler U., (2009). Internationalisation of higher education: European experiences, Asia Pacific Education Review, 10 (1), pp. 93-106

26. Vapa-Tankosić, J., Matijašević, J., Lazar, M., (2010). Internationalization of Higher Education: Strengthening HE Educational Reforms in Serbia on the Trajectory of EU Integration in Proceedings from International Conference \& Workshops on Higher Education, Partnership and Innovation, Budapest College of Communication and Business, pp. 243-253

27. Van der Wende M., (2001). Internationalisation policies: about new trends and contrasting paradigms, Higher Education Policy, 14 (3), pp. 249-259

28. Van Den Broeck, H., Kondakci, Y., Devos, G., (2006). More management concepts in the academy: internationalization as an organizational change process. Vlerick Leuven Gent Working Paper Series. Gent; Belgium, Vlerick Leuven Gent Management School, pp. 1-38

29. Wiley, D., (2007). On the Sustainability of Open Educational Resource Initiatives in Higher Education, OECD, Centre for Educational Research and Innovation (CERI) for the project on Open Educational Resources

30. Yang, R., (2002). University internationalization: its meanings, rationales and implications, Intercultural Education, 13 (1), pp. 81-95 